\title{
VACCINATION WITH INTERLEUKIN 2 GENE-TRANSFECTED-TUMOR INDUCED TUMOR-REACTIVE LYMPHOCYTES IN THE LOCAL LYMPH NODES OF TUMOR-BEARING IMMUNOCOMPROMISED MICE
}

\author{
Shuji Kurane ${ }^{1,4}$, Eiji Watari ${ }^{2}$, John C. Krauss ${ }^{3}$ and Shoji Kudoh ${ }^{1}$ \\ 'Fourth Department of Internal Medicine and '2Department of Microbiology and Immunology, Nippon Medical School, Bunkyoku, \\ Tokyo 113, Japan, and ${ }^{3}$ The Cleveland Clinic Foundation, Cleveland, $\mathrm{OH} 44195$, U.S.A.
}

\begin{abstract}
The efficacy of adoptive immunotherapy (AIT) using regional lymph node (RLN) cells draining cytokine-gene-transduced tumor vaccine in tumor-bearing immunocompromised mice was investigated. Fibrosarcoma cell line (MCA205) was infected with recombinant retrovirus carrying interleukin (IL) $2 \mathrm{cDNA}$ in vitro, irradiated and used as a tumor vaccine. Experimental treatment using this vaccine for syngeneic C57BL/6 mice with established MCA205 lung metastases did not exert any anti-tumor activity. However, even in long-term MCA205-bearing immunocompromised mice, vaccination with IL2-secreting MCA205 induced tumor-reactive lymphocytes in the RLNs, and AIT using these lymphocytes after stimulation with anti-CD3 antibody and IL2 in vitro resulted in potent antitumor activity in mice bearing established MCA205 lung metastases. Parental MCA205 vaccine, however, failed to induce active RLN cells in mice under the same conditions. Furthermore, AIT using IL2-gene-transduced B16 melanoma vaccine primed RLN cells in long-term MCA205-bearing mice exerted therapeutic activity only in mice with B16 lung metastases, not in mice with MCA205 lung metastases. The present study confirmed that IL2-gene-transduced tumor vaccine induced tumor-specific local immunity in an immunocompromised state corresponding to clinical situations, and AIT using RLN cells primed with this vaccine should be applicable to the treatment of advanced-stage cancer patients.
\end{abstract}

Hundreds of clinical cancer gene therapy trials are currently in progress around the world (14). A large number of the protocols employ a strategy designed to augment host anti-tumor immunity by using autologous tumors genetically engineered to secrete cytokines as vaccines. These studies are mainly based on experimental data from a variety of murine tumor models $(6-8,10,20,24)$. However, this strategy has had only a marginal effect on established tumors. Major obstacles to this approach may have existed in some conditions (i.e., even if this procedure augmented host antitumor immunity, the magnitude of the vaccination

${ }^{4}$ Correspondence to: S. Kurane. Tel: (81) 3-5814-6266; Fax: (81) 3-5685-3075; E-mail: skurane@nms.ac.jp. property, in most cases, may not have been strong enough to eradicate large numbers of tumor cells; or the magnitude may have been reduced during the tumor-bearing immunocompromised condition.) To overcome this difficulty, further study to extend these encouraging results needs to be pursued.

Our research has focused on the anti-tumor effect of adoptively transferred cells from lymph nodes draining growing tumors $(22,23)$. This strategy involves initial stimulation of lymph node cells by local tumor inoculation in vivo followed by sequential stimulation of the cells with anti-CD3 antibody and IL2 in vitro. This procedure has resulted in generation of large numbers of tumorreactive lymphocytes that exert potent, specific 
anti-tumor activity when adoptively transferred to a host with established lung metastases. Furthermore, the regional lymph node cells of the cytokine (GM-CSF and IL4) gene-transduced tumor are more potent than those of cytokine-nonsecreting parental tumors $(1,12,13)$. However, this attractive procedure may need to be modified in several respects before its clinical application. We, therefore, evaluated the anti-tumor activity of this strategy under conditions more relevant to clinical situations, i.e., using gene-transduced bulk tumor cells instead of established tumor lines stably transduced to secrete cytokines, using irradiated (non-growing) tumors as vaccines instead of nonirradiated (growing) tumors, and allowing to generate tumor-reactive-lymphocyte in long-term tumorbearing immunocompromised mice instead of naive mice.

\section{MATERIALS AND METHODS}

\section{Mice}

Female C57BL/6J (B6) mice, 6-8 weeks old, were purchased from the Charles River Japan (Kanagawa, Japan) and maintained under specific pathogen-free conditions. They were used in experiments at 8 weeks of age or older. The groups in all experiments consisted of 5 mice each.

\section{Tumor}

MCA205 tumor is a fibrosarcoma cell line induced by 3-methylcholanthrene in a B6 mouse and has been characterized as weakly immunogenic (4). B16-BL6 melanoma (kindly provided by $\mathrm{Dr} N$. Saijo, National Cancer Center, Tokyo) is a tumor of spontaneous origin that has been studied extensively (11). They are maintained by in vitro passage in complete media (CM). The CM consisted of RPMI 1640 medium supplemented with $10 \%$ heat-inactivated fetal calf serum, $0.1 \mathrm{mM}$ nonessential amino acids, $1 \mathrm{mM}$ sodium pyruvate, 100 $\mathrm{mg} / \mathrm{ml}$ streptomycin, $1,000 \mathrm{U} / \mathrm{ml}$ penicillin, 50 $\mathrm{mg} / \mathrm{ml}$ gentamicin, $0.5 \mathrm{mg} / \mathrm{ml}$ Fungizon (all from Gibco BRL, Grand Island, NY), and $5 \times 10^{-5} \mathrm{M} 2$ mercaptoethanol (Sigma Chemical).

\section{Recombinant Retroviruses and Virus-Infected Tumor Cells}

Plasmid DNA subcloning was carried out by standard techniques using reagents obtained from New England Biolabs (Tozer, MA, U.S.A.) (18). All the recombinant viruses have been described $(1,12$, 19). Briefly, pMFG IL2 was produced by isolating the BamH1 fragment containing the murine IL2 cDNA from pLJ IL2 and cloning it into the BamH1 site of pMFG. pMFG IL4 was produced by isolating the BamH1 fragment containing the murine IL4 cDNA from pLJ IL4 and cloning it into the BamH1 site of pMFG. Retrovirus vectors were co-transfected with the selectable marker pSV2Neo into $\psi$ crip cells as previously described (5). Recombinant retrovirus producer cell clones were isolated for generation of high titer viruses and used for transduction of tumor cells. Recombinant retrovirus carrying cytokine cDNA is referred to as 'cytokine-virus' below. Cytokine-secreting MCA205 or B16 tumors were created by infecting the exponentially growing tumor cells with $5 \mathrm{ml}$ of virus supernatant in the presence of polybrene $(8$ $\mu \mathrm{g} / \mathrm{ml}$ ) at $37^{\circ} \mathrm{C}, 5 \% \mathrm{CO}_{2}$, for $48 \mathrm{~h}$. To achieve high transduction efficiency, cells were exposed twice, replacing virus supernatants $24 \mathrm{~h}$ after the start of infection. The virus-infected tumors were then propagated in $\mathrm{CM}$ and used within 7 days after infection. Cytokine production by the bulk tumor was assessed in $24 \mathrm{~h}$ culture medium, immediately prior to use as the tumor vaccine.

\section{Cytokine Assay}

IL2 secretion by the IL2-virus-infected tumor was evaluated by using IL2-dependent cell line HT-2 (ATCC, Rockville, MD), to determine IL2 concentrations (15). Briefly, $1 \mathrm{ml}$ of media conditioned by growing $1 \times 10^{6}$ tumor cells 7 days after IL2-virus infection for $24 \mathrm{~h}$ was assayed for IL2 content in a standard 3-[4, 5-dimethylthiazol-2-yl]-2, 5-diphenyltetrazolium bromide (MTT) proliferation assay, with recombinant mouse IL2 (Pharmingen, San Diego, CA) as a known standard run in parallel. To evaluate IL4 secretion, supernatants of the IL4virus infected tumor cells were assayed by ELISA (Pharmingen, San Diego, CA) with recombinant murine IL4 (Boehringer-Mannheim) as a known standard run in parallel.

\section{Tumor-Bearing Mice}

B6 mice inoculated intravenously (i.v.) with $4 \times$ $10^{5}$ of parental MCA205 tumor or B16 melanoma cells in $1 \mathrm{ml}$ of HBSS were used for all the therapy experiments and are referred to as 'tumor-bearing mice' below. For the vaccine therapy experiments, 3-day tumor-bearing mice were used as recipients. 
Ten-day tumor-bearing mice were also used to induce tumor-reactive regional lymph nodes (RLNs) in some adoptive immunotherapy (AIT) experiments. RLNs from naive mice were used as control RLN donors. All the mice inoculated i.v. with tumor cells developed lung metastases, and the lung metastases were counted as follows. The mice were killed days 21 to 24 after tumor inoculation, their lungs were insufflated with Fekette's solution (21). Pulmonary metastases were counted without knowledge of the treatment. In all experiments, lungs with pulmonary nodules too numerous to count were arbitrarily assigned a value of $>250$ for statistical analysis.

\section{Therapeutic Efficacy of Inoculation of Irradiated Cytokine-Producing Tumor as a Vaccine}

MCA205 tumor cells infected with IL2 or IL4 retrovirus for 7 days were trypsinized and then washed twice in HBSS. Cytokine-virus-non-infected parental tumor was used as a control. Cells were suspended in HBSS at a density of $1 \times$ $10^{7} / \mathrm{ml}$ and irradiated with $6,000 \mathrm{rads}$ (Ohmicron, Soft X-ray unit; Ohmic, Tokyo, Japan). To evaluate the vaccination properties of the cytokine-genetransduced tumors, 3-day tumor-bearing mice were injected in the flank intradermally (i.d.) with $3 \times$ $10^{6}$ or $1.2 \times 10^{7}$ of cytokine-virus-infected or noninfected irradiated MCA205 tumor cells in $0.1 \mathrm{ml}$ of HBSS. Twenty days after vaccination, mice were sacrificed and lung metastases were counted as described above.

\section{Generation of Tumor-Reactive Regional Lymph Node Cells}

We assessed several conditions for generation of tumor-reactive RLN cells as follows. 1) Naive B6 mice were inoculated i.d. with $3 \times 10^{6}$ of parental or cytokine-virus-infected non-irradiated MCA205 tumors (results shown in Table 3). 2) Naive or 10day MCA205 tumor-bearing B6 mice were inoculated i.d. with $3 \times 10^{6}$ of parental or cytokinevirus-infected non-irradiated MCA205 tumor (results shown in Table 4). 3) Naive or 10-day MCA205 tumor-bearing B6 mice were inoculated i.d. with $3 \times 10^{6}$ of parental or cytokine-virusinfected irradiated MCA205 tumor cells (results shown in Table 5). 4) Naive B6 mice were inoculated i.d. with $3 \times 10^{6}$ of irradiated MCA205 or B16 melanoma cells (results shown in Fig. 1). 5)
Ten-day MCA205 tumor-bearing B6 mice were inoculated i.d. with $9 \times 10^{6}$ of parental or cytokine-virus-infected irradiated MCA205 tumor cells (results shown in Table 6). 6) Ten-day MCA205 tumor-bearing B6 mice were inoculated i.d. with $9 \times 10^{6}$ of IL2-virus-infected irradiated MCA205 tumor or B16 melanoma cells (results shown in Table 7 and Fig. 2). Tumor cells were suspended in $0.1 \mathrm{ml}$ of HBSS before inoculation and were inoculated in the flank intradermally. Ten days after tumor inoculation, RLNs (ipsilateral inguinal lymph nodes) were harvested under sterile conditions. Lymphocytes were dissociated into single cell suspensions by teasing the LN apart with 25-gauge needles and then pressing the $\mathrm{LN}$ with the blunt end of a $10 \mathrm{ml}$ plastic syringe.

\section{In Vitro Anti-CD3/IL2 Activation of Regional Lymph Node Cells}

RLN cells from tumor-inoculated mice were activated for 2 days in vitro with immobilized antiCD3 antibody (145-2C11: Boehringer-Mannheim) in 24-well tissue culture plates at $4 \times 10^{6}$ cells/well. The cells were then harvested, washed and expanded in 24-well plates in CM supplemented with $50 \mathrm{u} / \mathrm{ml}$ of recombinant human (rh) IL2 (kindly provided by the Shionogi Pharmaceutical, Osaka, Japan) at $4 \times 10^{5}$ cells/well. The cells were subsequently harvested, washed, and resuspended in $1 \mathrm{ml}$ HBSS for adoptive immunotherapy.

\section{In Vitro Cytotoxicity Assay}

In order to evaluate the tumor-specific cytotoxic activity of anti-CD3/IL2 activated RLN cells in vitro, ${ }^{51} \mathrm{Cr}$ release assays were performed (16). Ten million of target cells (MCA205 or B16) were labeled with ${ }^{51} \mathrm{Cr}\left(\mathrm{Na}^{51} \mathrm{CrO}_{4} ; 100 \mu \mathrm{Ci}\right.$; New England Nuclear, Boston, $\mathrm{MA}$ ) at $37^{\circ} \mathrm{C}$ for $1 \mathrm{~h}$ and washed three times with $\mathrm{CM}$. Ten thousand of ${ }^{51} \mathrm{Cr}$-labeled tumor cells were incubated with various numbers of effector cells at $37^{\circ} \mathrm{C}, 5 \% \mathrm{CO}_{2}$ in a volume of $0.2 \mathrm{ml}$ of $\mathrm{CM}$ in round-bottomed 96well plates for $4 \mathrm{~h}$ (4-h assay) or $16 \mathrm{~h}$ (16-h assay). After incubation, supernatants were collected and samples were counted in a gamma counter. For maximal ${ }^{51} \mathrm{Cr}$ release, $2 \%$ Triton $\mathrm{X}$ was added. The percent lysis was calculated according to the following equation:

$\%$ lysis $=100 \times($ experimental $\mathrm{cpm}-$ spontaneous $\mathrm{cpm}) /($ maximal cpm - spontaneous cpm)

To confirm tumor specific activity of RLN cells, 
cris-cross experiments were performed by using RLNs draining $3 \times 10^{6}$ of irradiated MCA205- or B16 melanoma-vaccine in naive mice (results shown in Fig. 1). We also investigated the specificity of tumor vaccine by using RLNs draining 9 $\times 10^{6}$ of IL2-virus-infected irradiated MCA205vaccine or B16 melanoma-vaccine in a long-term MCA205-baring mice (results shown in Fig. 2).

\section{Procedure for Adoptive Immunotherapy}

Three-day tumor-bearing mice were injected i.v. with $3 \times 10^{6}$ to $7.2 \times 10^{7}$ of anti-CD3/IL-2 activated RLN cells from each type of tumor-bearing mice, as described above. Mice were also injected intraperitoneally (i.p.) with $10,000 \mathrm{U}$ of rhIL2 in $0.5 \mathrm{ml} \mathrm{HBSS}$ i.p. twice a day for 4 days to maintain the in vivo proliferation and anti-tumor reactivity of the transferred cells. The mice were killed 22 to 24 days after tumor inoculation, and their lungs were insufflated and pulmonary metastases were counted as described above.

\section{Statistical Analysis}

The significance of differences in the number of pulmonary metastases between groups was determined by the Wilcoxon rank-sum test (9). Twosided $P$ values of $P<0.05$ were considered statistically significant. No animals were excluded from the statistical analysis.

\section{RESULTS}

\section{Cytokine Secretion by Recombinant-Retrovirus-} Infected Tumor Cells

Cytokine production by cytokine-virus-infected bulk MCA205 tumor was assessed 7 days after infection. IL2 production by tumor exposed to IL2virus twice for $48 \mathrm{~h}$ ranged from 13.7 to 24.3 $\mathrm{u} / 10^{6} / 24 \mathrm{~h}$. These amounts were about $25 \%$ to $60 \%$ higher than after single exposure. IL4 secretion by bulk MCA205 exposed to IL4 virus twice ranged from 7.8 to $20.4 \mathrm{U} / 10^{6} / 24 \mathrm{~h}$. These amounts were also $30 \%$ to $50 \%$ higher than after single exposure (Table 1). Bulk B16 melanoma exposed to IL2virus twice produced $24.2 \mathrm{u} / 10^{6} / 24 \mathrm{~h}$ of IL2 (Table 7). However, cytokine secretion rapidly diminished and the amounts at day 10 after virus infection were about half of the amounts at day 7 (data not shown). Irradiated tumor also reduced cytokine secretion during culture, however, the amounts produced at 5 days after irradiation (12 days after virus infection) were still about half of those produced 7 days after virus infection (data not shown).

\section{Vaccination Effect of Irradiated Cytokine- Secreting Tumors}

Irradiated parental MCA205 tumor vaccine $(3 \times$ $10^{6}$ or $9 \times 10^{6}$ cells) did not show any anti-tumor activity for the mice with 3-day established MCA205 lung metastases. Nor did the same number of irradiated IL2-secreting MCA205 tumor cells and IL4-secreting MCA205 tumor cells show any reduction in the number of metastases (Table 2).

\section{Cytotoxicity of Activated Regional Lymph Node Cells in Vitro}

To evaluate the tumor-specific cytotoxic activity of anti-CD3/IL2 activated RLN cells, criss-cross experiments were performed. Activated RLN cells of MCA205-vaccine or B16 melanoma-vaccine were tested for their cytotoxic activity against these tumors. Standard $4-\mathrm{h}{ }^{51} \mathrm{Cr}$ release assay did not show any detectable activity of each activated RLN cells (data not shown). Sixteen-h assay, however, could reveal the specific activity of these activated RLN cells (Fig. 1). Although activated MCA205 tumor vaccine did not induce cytotoxic cells, IL2-secreting irradiated MCA205 tumor vaccine induced MCA205 specific RLN cells in a long-term MCA205-baring mice (Fig. 2). Furthermore, IL2-secreting irradiated B16 melanoma vaccine induced B16 melanoma specific RLN cells in a long-term MCA205-baring mice (Fig. 2). These RLN cells, however, did not exert any detectable cytotoxicity against MCA205 tumor (Fig. 2A).

\section{Adoptive Immunotherapy Experiments}

AIT using RLNs draining parental MCA205 tumor from naive mice displayed anti-tumor activity. RLNs draining non-irradiated IL2- or IL4- secreting MCA205 tumors also showed strong therapeutic activity, though the difference between the groups was not significant (Table 3 ). While RLN cells from non-irradiated tumors of 10- to 20-day tumor-bearing mice had lower therapeutic efficacy than RLN cells from naive mice, RLN cells from cytokine-secreting MCA205 tumors had marginal superiority over those from parental tumors (Table 4). Vaccination with irradiated (non-growing) 
Table 1 Cytokine Production by Cytokine-Virus ${ }^{\mathrm{a}}{ }_{\text {-Infected }}$ MCA205 Tumor

\begin{tabular}{c|cc}
\hline Cytokine-virus infection & IL2 $\left(\mathrm{u} / 10^{6} / 24 \mathrm{~h}\right)$ & $\mathrm{IL} 4\left(\mathrm{u} / 10^{6} / 24 \mathrm{~h}\right)$ \\
\hline Control & $\mathrm{ND}^{\mathrm{d})}$ & $\mathrm{ND}$ \\
IL2-virus $\times 1^{\mathrm{b})}$ & $\left.12.0 \pm 2.8^{\mathrm{e}}\right)$ & $\mathrm{ND}$ \\
$\times 2^{\mathrm{c})}$ & $17.7 \pm 2.7$ & $\mathrm{ND}$ \\
IL4-virus $\times 1$ & $\mathrm{ND}$ & $8.3 \pm 2.8$ \\
$\times 2$ & $\mathrm{ND}$ & $13.6 \pm 5.1$ \\
\hline
\end{tabular}

a) Recombinant retrovirus carrying mIL2 or mIL4 cDNA was used for cytokine gene transduction into MCA205 tumor. ${ }^{\text {b) Tumor }}$ exposed to IL2-virus once. ${ }^{c}$ Tumor exposed to IL2-virus twice. ${ }^{\mathrm{d}}$ Not detected. ${ }^{\mathrm{e}}$ Data represent 24 -h cytokine production by $1 \times$ $10^{6}$ infected MCA205 tumor cells 7 days after virus infection (means \pm SD of eight experiments).

Table 2 Treatment of Established Lung Metastases with Cytokine-Virus-Infected Irradiated MCA205 as Tumor Vaccine

\begin{tabular}{lc|cc|cc}
\hline \multicolumn{2}{c|}{ Source of vaccine } & \multicolumn{2}{c|}{ Experiment 1 } & \multicolumn{2}{c}{ Experiment 2 } \\
\hline Tumor $^{\mathrm{a})}$ & $\begin{array}{c}\text { Number of cells } \\
\text { inoculated }\end{array}$ & $\begin{array}{c}\text { Cytokine } \\
\text { production } \\
\left(\mathrm{u} / 10^{6} / 24 \mathrm{~h}\right)\end{array}$ & $\begin{array}{c}\text { Mean number of lung } \\
\left.\text { metastases }^{\mathrm{c}}\right)\end{array}$ & $\begin{array}{c}\text { Cytokine } \\
\text { production } \\
\left(\mathrm{u} / 10^{6} / 24 \mathrm{~h}\right)\end{array}$ & $\begin{array}{c}\text { Mean number of lung } \\
\text { metastases }\end{array}$ \\
\hline- & - & - & $>250$ & - & $>250$ \\
\hline WT & $3 \times 10^{6}$ & - & $>250$ & - & $\mathrm{ND}^{\mathrm{d})}$ \\
WT & $1.2 \times 10^{7}$ & - & $>250$ & - & $>250$ \\
IL2 & $3 \times 10^{6}$ & 16.9 & $>250$ & 20.1 & $\mathrm{ND}$ \\
IL2 & $1.2 \times 10^{7}$ & 16.9 & 226 & - & $\mathrm{ND}$ \\
IL4 & $3 \times 10^{6}$ & 9.6 & $>250$ & 16.2 & $>250$ \\
IL4 & $1.2 \times 10^{7}$ & 9.6 & $>250$ & & -250 \\
\hline
\end{tabular}

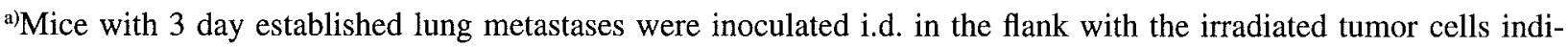
cated as vaccine. WT, parental MCA205; IL2, IL2-virus-infected MCA205; IL4, IL4-virus-infected MCA205. b)24$\mathrm{h}$ cytokine production by $1 \times 10^{6} \mathrm{MCA} 205$ tumor cells 7 days after virus infection. ${ }^{\mathrm{c}}$ Lung metastases were counted 21 days after vaccination. Data represent means for 5 mice. ${ }^{\text {d) Not determined }}$

MCA205 tumors greatly reduced the activity of RLN cells in both naive and tumor-bearing mice when $1.2 \times 10^{7}$ cells were transferred (Table 5). However, when the inoculated cell number was increased from $3 \times 10^{6}$ to $9 \times 10^{6}$ and the number of RLN cells transferred was also increased from $1.2 \times 10^{6}$ to $3.6 \times 10^{7} /$ mouse, AIT with RLNs draining irradiated IL2-secreting MCA205 tumors in MCA205 tumor-bearing mice significantly reduced the number of lung metastasis as compared to AIT using irradiated parental tumor $(P<$ 0.05). AIT using RLNs draining irradiated IL4secreting MCA205 tumor showed marginal superiority over RLNs draining irradiated parental tumor (Table 6). AIT using RLNs draining irradiated IL2- secreting B16 melanoma vaccine in 10-day MCA205 tumor-bearing mice exerted therapeutic activity only for the mice with 3-day B16 melanoma-bearing mice, but not for the mice with 3-day MCA205 tumor-bearing mice (Table 7).

\section{DISCUSSION}

In this study we used recombinant retrovirus to transduce mouse IL2 or IL4 genes into MCA205 tumor and B16 melanoma cells. IL2 is one of the most extensively investigated Th1 type cytokines and is capable not only of stimulating the proliferation of T lymphocytes and natural killer (NK) cells but of enhancing their cytotoxic activity. IL2 has 
A B
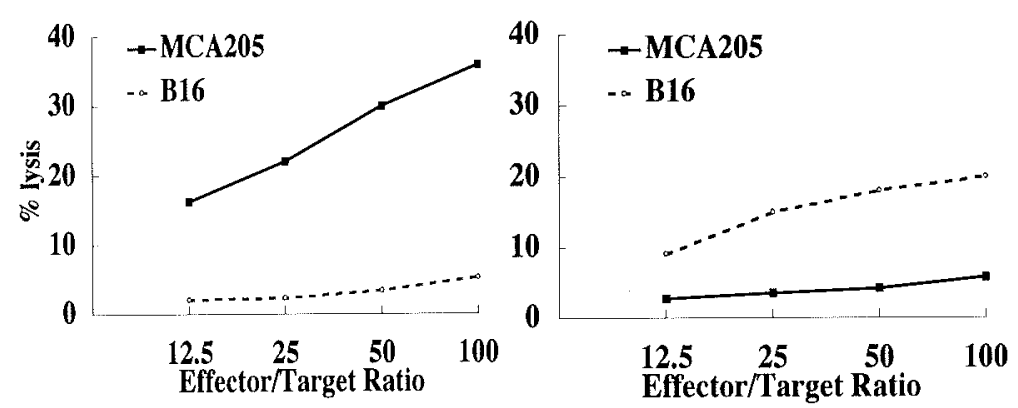

Fig. 1 A: Lysis of MCA205 tumor target cells (solid line) or B16 melanoma target cells (dotted line) by activated lymph node (LN) cells induced from regional LN draining MCA205 tumor in naive mice. B: Lysis of MCA205 tumor target cells (solid line) or B16 melanoma target cells (dotted line) by activated LN cells induced from regional LN draining B16 melanoma in naive mice
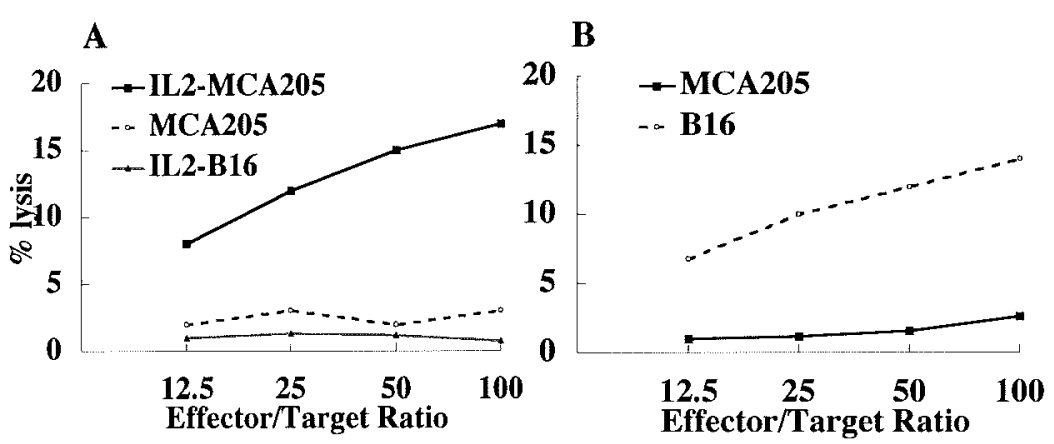

Fig. 2 A: Lysis of MCA205 tumor target cells by activated lymph node (LN) cells induced from regional LN draining irradiated MCA205 tumor (dotted line), IL2-virus-infected irradiated MCA205 tumor (solid line) or IL2-virusinfected irradiated B16 melanoma (gray line) in long-term MCA205 tumor-bearing mice. B: Lysis of MCA205 tumor target cells (solid line) or B16 melanoma target cells (dotted line) by activated LN cells induced from regional LN draining IL2-virus-infected irradiated B16 melanoma in long-term MCA205 tumor-bearing mice

also been confirmed to stimulate human B cell proliferation and antibody synthesis. While IL4 has been found to activate the immune system by inducing proliferation of $\mathrm{B}$ cells, $\mathrm{T}$ cells and cells of non-lymphocyte lineage. Both cytokines can stimulate effector cells for tumor eradication. Hence it seemed of interest to analyze the host immune response against these cytokine-transduced tumors. We recently established IL2-, IL4and GM-CSF-secreting murine fibrosarcoma (MCA205) lines and compared their vaccination efficacy and usefulness for AIT by using cytotoxic lymphocytes generated by lymph nodes draining these tumors growing in naive mice (13). In the present study, we further evaluated whether our system could work under conditions more relevant to clinical situations. When used in actual clinical situations, patients may have residual tumor and may be immunologically depressed. This made it necessary to determine whether this procedure could induce active lymph node cells under immunocompromised conditions. Furthermore, in the former study we used cytokine-genes transduced stable tumor lines without irradiation. However, these selected clones may have obtained some specific characteristics different from those of the parental tumor during the cloning procedure, and that might have affected the experimental data. Moreover, tumor vaccines should be irradiated before inoculation so that they do not grow in vivo in clinical situations. We, therefore, used irradiated bulk tumor within 7 days after cytokine-virus infection. As shown in Table 1, IL2-virus infected tumor produced $13.7-24.3 \mathrm{u} / 10^{6} / 24 \mathrm{~h}$ shortly before inoculation, and therapeutic vaccination had no efficacy on established tumors. However, as shown 
Table 3 Adoptive Immunotherapy of Established Lung Metastases with Activated Lymphocytes Generated by Regional Lymph Nodes (RLNs) Draining Cytokine-Virus Infected Non-Irradiated MCA205 Tumors in Naive Mice

\begin{tabular}{cc|cc}
\hline $\begin{array}{c}\text { Source of RLN cells } \\
\text { Tumor } \\
\left(3 \times 10^{6}\right)\end{array}$ & $\begin{array}{c}\text { Cytokine } \\
\text { production }^{\mathrm{b})}\end{array}$ & RLN cells transferred & Mean number of lung metastases (SEM) ${ }^{\mathrm{d})}$ \\
\hline- & - & - & $>250$ \\
WT & - & $6 \times 10^{6}$ & $47.7(12.5)^{\mathrm{e})}$ \\
WT & - & $1.2 \times 10^{7}$ & $16.4(4.2)^{\mathrm{c})}$ \\
IL2 & 16.9 & $6 \times 10^{6}$ & $12.0(5.3)^{\mathrm{e}}$ \\
IL2 & 16.9 & $1.2 \times 10^{7}$ & $6.4(2.1)^{\mathrm{e}}$ \\
IL4 & 9.6 & $6 \times 10^{6}$ & $10.2(4.2)^{\mathrm{c})}$ \\
IL4 & 9.6 & $1.2 \times 10^{7}$ & $3.2(2.1)^{\mathrm{e}}$ \\
\hline
\end{tabular}

a) Mice were inoculated i.d. in the flank with $3 \times 10^{6}$ cytokine-virus-infected tumor cells. WT, parental MCA205; IL2, IL2-virus infected MCA205; IL4, IL4-virus infected MCA205. Ten days later, regional lymph nodes draining the tumor were harvested and activated in vitro with anti-CD3

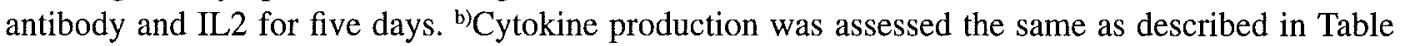
2. 'Mice with 3-day established lung metastases were treated with anti-CD3/IL2 activated RLN cells. ${ }^{d}$ Data represent means \pm SEM for 5 mice. ${ }^{e} P<0.05$ compared with control group

Table 4 Adoptive Immunotherapy for Established Lung Metastases with the Regional Lymph Nodes (RNLs) Draining Cytokine-Virus Infected Non-Irradiated MCA205 Tumors in Naive or Tumor-Bearing Mice

\begin{tabular}{|c|c|c|c|c|c|c|}
\hline \multicolumn{3}{|c|}{ Source of RLN cells } & \multicolumn{2}{|c|}{ Experiment 1} & \multicolumn{2}{|c|}{ Experiment 2} \\
\hline Mice & $\begin{array}{l}\text { Tumor }{ }^{\text {c) }} \\
\left(3 \times 10^{6}\right)\end{array}$ & $\begin{array}{l}\text { RLN cell } \\
\text { transferred }\end{array}$ & $\begin{array}{l}\text { Cytokine } \\
\text { production }^{\mathrm{d})}\end{array}$ & $\begin{array}{l}\text { Mean number of lung } \\
\text { metastases (SEM) }\end{array}$ & $\begin{array}{l}\text { Cytokine } \\
\text { production }{ }^{\mathrm{d})}\end{array}$ & $\begin{array}{l}\text { Mean number of lung } \\
\text { metastases (SEM) }\end{array}$ \\
\hline - & 一 & 一 & - & $>250$ & - & $>250$ \\
\hline Naive $^{\text {a) }}$ & $\begin{array}{l}\text { WT } \\
\text { IL2 } \\
\text { IL4 }\end{array}$ & $\begin{array}{l}1.2 \times 10^{7} \\
1.2 \times 10^{7} \\
1.2 \times 10^{7}\end{array}$ & $\begin{array}{l}- \\
17.3 \\
14.0\end{array}$ & $\begin{array}{l}11.4(6.1)^{\mathrm{f}} \\
7.0(2.1)^{\mathrm{f}} \\
1.2(0.6)^{\mathrm{f}}\end{array}$ & $\begin{array}{l}- \\
20.4 \\
12.8 \\
\end{array}$ & $\begin{array}{r}23.4(9.3)^{\mathrm{f}} \\
13.2(4.0)^{\mathrm{n}} \\
7.6(3.9)^{\mathrm{n}} \\
\end{array}$ \\
\hline Tumor-baring ${ }^{\mathrm{b})}$ & $\begin{array}{l}\text { WT } \\
\text { IL2 } \\
\text { ILA }\end{array}$ & $\begin{array}{l}1.2 \times 10^{7} \\
1.2 \times 10^{7} \\
1.2 \times 10^{7}\end{array}$ & $\begin{array}{l}- \\
17.3 \\
14.0\end{array}$ & $\begin{array}{c}126.8(39.0) \\
41.0(12.3)^{\curvearrowleft} \\
80.4(26.8)\end{array}$ & $\begin{array}{l}- \\
20.4 \\
12.8\end{array}$ & $\begin{array}{r}150.8(25.4) \\
35.8(10.8)^{\mathrm{f}} \\
37.4(16.8)^{\mathrm{f}}\end{array}$ \\
\hline
\end{tabular}

a) Naive mice were inoculated i.d. in the flank with $3 \times 10^{6}$ tumor cells that had been infected with cytokine-virus for

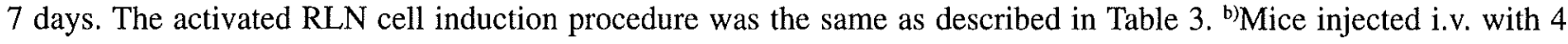
$\times 10^{5}$ MCA205 cells ten days previously were used as tumor-bearing animals. The activated RLN cell induction procedure was the same as above. ${ }^{c}$ WT, Parental MAC205; IL2, MCA205 infected with IL2-virus; IL4, MCA205

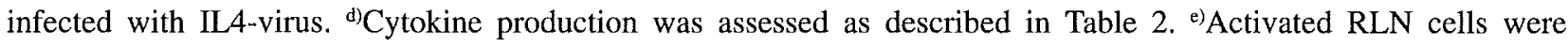
transferred to the mice with 3-day established lung metastases. Data represent means \pm SEM for 5 mice. ${ }^{n} P<0.05$ compared with control group

in Table 5 and Table 6, IL2-virus-infected irradiated tumor vaccine produced potent anti-tumor RLN cells even in tumor-bearing mice, although large numbers of vaccine cells and activated RLN cells were needed to exert a therapeutic effect. RLN cells from irradiated parental MCA205, however, failed to reduce metastases under these conditions. In our previous study (13), IL2 secretion by a non- irradiated tumor line had no effect under the same conditions, as indicated in Table 3 . This discrepancy may be explained by excessive IL 2 secretion by the tumor reducing induction of tumor-specific cytotoxic cells by activating non-specific cytotoxic cells, such as NK cells and LAK cells and rapid tumor eradication (the tumor line we used in our previous study secreted $140 \mathrm{u} / 10^{6} / 24 \mathrm{~h}$ of IL2). 
Table 5 Adoptive Immunotherapy of Mice with Established Lung Metastases Using Regional Lymph Nodes (RLNs) Draining Cytokine-Virus Infected Irradiated MCA205 Tumors in Naive or Tumor-Bearing Mice

\begin{tabular}{|c|c|c|c|c|c|c|}
\hline \multicolumn{3}{|c|}{ Source of RLN cells } & \multicolumn{2}{|c|}{ Experiment 1} & \multicolumn{2}{|c|}{ Experiment 2} \\
\hline Mice $^{\text {a) }}$ & $\begin{array}{c}\text { Tumor }{ }^{b)} \\
\left(3 \times 10^{6}\right)\end{array}$ & $\begin{array}{l}\text { RLN cell } \\
\text { transferred }\end{array}$ & $\begin{array}{l}\text { Cytokine } \\
\text { production }^{\mathrm{c})} \\
\left(\mathrm{u} / 10^{6} / 24 \mathrm{~h}\right)\end{array}$ & $\begin{array}{l}\text { Mean number of lung } \\
\text { metastases } \\
(\text { SEM })^{\mathrm{d})}\end{array}$ & $\begin{array}{l}\text { Cytokine } \\
\text { production }^{\text {c) }} \\
\left(\mathrm{u} / 10^{6} / 24 \mathrm{~h}\right)\end{array}$ & $\begin{array}{l}\text { Mean number of lung } \\
\text { metastases } \\
(\mathrm{SEM})^{\mathrm{d})}\end{array}$ \\
\hline - & - & - & - & $>250$ & - & $>250$ \\
\hline Naive & $\begin{array}{l}\text { WT } \\
\text { IL2 } \\
\text { IL4 }\end{array}$ & $\begin{array}{l}1.2 \times 10^{7} \\
1.2 \times 10^{7} \\
1.2 \times 10^{7}\end{array}$ & $\begin{array}{l}- \\
13.7 \\
16.2\end{array}$ & $\begin{array}{r}142.2(28.4) \\
72.8(22.7) \\
53.0(20.8)^{\mathrm{e})}\end{array}$ & $\begin{array}{r}- \\
20.4 \\
9.6\end{array}$ & $\begin{array}{l}147.6(37.3) \\
102.4(29.6) \\
135.0(30.3)\end{array}$ \\
\hline Tumor-bearing & $\begin{array}{l}\text { WT } \\
\text { IL2 } \\
\text { IL4 }\end{array}$ & $\begin{array}{l}1.2 \times 10^{7} \\
1.2 \times 10^{7} \\
1.2 \times 10^{7}\end{array}$ & $\begin{array}{l}- \\
13.7 \\
16.2\end{array}$ & $\begin{array}{c}>250 \\
137.8(23.6) \\
194.8(69.6)\end{array}$ & $\begin{array}{r}- \\
20.4 \\
9.6\end{array}$ & $\begin{array}{c}>250 \\
138.0(34.5) \\
171.8(79.0)\end{array}$ \\
\hline
\end{tabular}

${ }^{a}$ Naive and tumor-bearing mice as in Table $4 .{ }^{\circ} 3 \times 10^{6}$ irradiated tumors cells were used as vaccine. WT, parental MCA205; IL2, MCA205 infected with IL2-virus; IL4, MCA205 infected with IL4-virus. Activated RLN cell induction procedure was the same as descreibed in Table 3. ${ }^{c}$ Cytokine production were assessed as in Table 2. ${ }^{d)}$ Activated RLN cells were transferred to the mice with 3 -day established lung metastases. Data represent means \pm SEM for 5 mice. ${ }^{\text {e) } P}<0.05$ compared with control group

Table 6 Adoptive Immunotherapy of the Mice with Established Lung Metastases Using the Regional Lymph Nodes (RLNs) Draining Cytokine-Virus Infected Irradiated MCA205 Tumors in Tumor-Bearing Mice ${ }^{\text {a) }}$

\begin{tabular}{cc|cc|cc}
\hline \multicolumn{2}{c|}{$\begin{array}{c}\text { Source of } \\
\text { RLN cells }\end{array}$} & \multicolumn{2}{c|}{ Experiment 1 } & \multicolumn{2}{c}{ Experiment 2 } \\
$\begin{array}{c}\text { Tumor } \\
\left(9 \times 10^{6}\right)\end{array}$ & $\begin{array}{c}\text { RLN cell } \\
\text { transferred }^{\mathrm{b}}\end{array}$ & $\begin{array}{c}\text { Cytokine } \\
\text { production }^{\mathrm{d})}\end{array}$ & $\begin{array}{c}\text { Mean number of lung } \\
\text { metastases (SEM) }\end{array}$ & $\begin{array}{c}\text { Cytokine } \\
\text { production }^{\mathrm{d})}\end{array}$ & $\begin{array}{c}\text { Mean number of lung } \\
\text { metastases (SEM) }^{\mathrm{e})}\end{array}$ \\
\hline- & - & - & $>250$ & & $>250$ \\
\hline WT & $1.2 \times 10^{7}$ & - & $>250$ & - & $>250$ \\
WT & $3.6 \times 10^{7}$ & - & $>250$ & - & $>250$ \\
IL2 & $1.2 \times 10^{7}$ & 20.1 & $41.8(15.8)^{\mathrm{f}}$ & 18.6 & $35.8(16.9)^{\mathrm{f}}$ \\
IL2 & $3.6 \times 10^{7}$ & 20.1 & $9.6(3.0)^{\mathrm{f}}$ & 18.6 & $15.4(8.9)^{\mathrm{f}}$ \\
IL4 & $1.2 \times 10^{7}$ & 18.9 & $135.0(33.0)$ & 14.0 & $188.0(51.5)$ \\
IL4 & $3.6 \times 10^{7}$ & 18.9 & $55.2(27.9)$ & 14.0 & $74.8(31.6)$ \\
\hline
\end{tabular}

a)Mice injected i.v. with $4 \times 10^{5}$ of MCA205 ten days previously were used as tumor-bearing animals. ${ }^{\text {b)Ten-day }}$

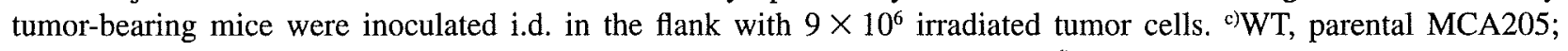
IL2, MCA205 infected with IL2-virus; IL4, MCA205 infected with IL4-virus. ${ }^{d}$ Cytokine production was assessed as

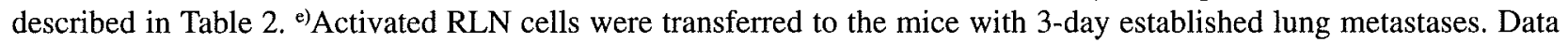
represent means \pm SEM for 5 mice. ${ }^{n} P<0.05$ compared with the group of mice treated with activated RLN cells after irradiated parental MCA205 vaccination

Another possible explanation is that the IL2-secreting tumor line used in our previous study may have possessed specific characteristics different from those of parental MCA205 tumor. While the IL4-secreting tumor also showed therapeutic activity as shown in Tables 3, 4, 5 and 6, the efficacy of IL4 may be slightly less than that of IL2 in tumorbearing immunocompromised mice (Table 6).
These results can be partly explained by a recent finding that Th2 type cytokine production predominates over Th1 type cytokines under immunocompromised conditions (17). Under such conditions, Th1 type cytokines (IL2) may be more efficacious than Th2 type cytokines (IL4) in altering the immunosuppressed states and enable generation of anti-tumor immunity. As we expected, irradiation 
Table 7 Adoptive Immunotherapy of Mice with Established Lung Metastases by Using Regional Lymph Nodes (RLNs) Draining IL2-Virus Infected Irradiated Tumors in MCA205 Tumor-Bearing Mice ${ }^{\text {a) }}$

\begin{tabular}{|c|c|c|c|c|}
\hline \multicolumn{3}{|c|}{ Source of RLN cells $\left.{ }^{b}\right)$} & \multicolumn{2}{|c|}{ Experimente) } \\
\hline $\begin{array}{l}\text { Tumor vaccine } \\
\qquad\left(9 \times 10^{6}\right)\end{array}$ & $\begin{array}{c}\text { IL2 } \\
\text { production }{ }^{\mathrm{d}}\end{array}$ & $\begin{array}{l}\text { RLN cells } \\
\text { transferred }\end{array}$ & $\begin{array}{l}\text { Mean number of B } 16 \\
\text { lung metastases (SEM) }\end{array}$ & $\begin{array}{l}\text { Mean number of MCA205 } \\
\text { lung metastases (SEM) }\end{array}$ \\
\hline - & - & - & $>250$ & $>250$ \\
\hline MCA205 & 22.6 & $3.6 \times 10^{7}$ & $\mathrm{ND}^{\mathrm{n}}$ & $14.2(4.7)$ \\
\hline MCA205 & 22.6 & $7.2 \times 10^{7}$ & $>250$ & $\left.N^{f}\right)$ \\
\hline B16 & 24.2 & $3.6 \times 10^{7}$ & $79.2 .8(25.8)$ & 238.8 \\
\hline B16 & $24: 2$ & $7.2 \times 10^{7}$ & $35.8(15.0)^{\mathrm{g})}$ & $189(46.1)$ \\
\hline
\end{tabular}

${ }^{a}$ Mice injected i.v. with $4 \times 10^{5}$ of MCA205 ten days previously were used as tumor-bearing animals. ${ }^{\text {b)Ten-day }}$ tumor-bearing mice were inoculated i.d. in the flank with $9 \times 10^{6} \mathrm{IL} 2$-virus infected irradiated MCA205 tumor cells

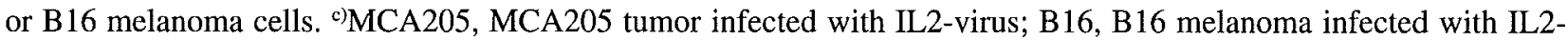

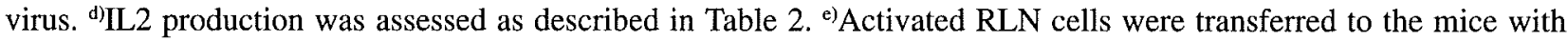
3-day established B16 or MCA205 lung metastases. Data represent means \pm SEM for 5 mice. ${ }^{\mathrm{f}}$ Not determined. ${ }^{\mathrm{g}} P$ $<0.05$ compared with the group of mice treated with $7.2 \times 10^{7}$ activated RLN cells after IL2-virus infected irradiated MCA205 tumor vaccination

to the tumor vaccine greatly reduced the tumorigenicity and the therapeutic efficacy of this procedure as compared to that using non-irradiated tumor vaccine. In addition, the vaccination effect was tumor-specific and limited to regional lymph nodes. Interestingly, IL2-secreting B16 melanoma vaccination in a long-term MCA205 tumor-baring mice induced the B16 melanoma specific RLN cells (Table 7, Fig. 2). We also found that therapeutic lymphocytes were not induced from distant lymph nodes (i.e., contralateral axillary or inguinal lymph nodes) or the spleen (data not shown). These results may indicate the existence of a threshold cytokine and antigen stimulation level for generation of effective tumor-specific immunity. In this study we did not evaluate the precise immunostatus of 10- to 20-day tumor-bearing mice. However, the lack of generation of antitumor lymphocytes by the RLNs after parental tumor vaccination may indicate the existence of low immunoreactivity against the tumor in longterm tumor-bearing mice.

Our preliminary cell subset analysis of RLN cells showed that the percentage of non- $T$, non-B cell population increased slightly in RLNs draining the parental tumor vaccine of 20-day tumor-bearing mice as compared to those of naive mice (data not shown). However, non T, non B cell population also increased after vaccination with IL2-secreting tumor. Although, more than $97 \%$ of cells were $\mathrm{CD}^{+}$after 5-days anti-CD3/LL2 stimulation under the conditions tested in this study (data not shown), they did not show any detectable in vitro cytotoxicity in a standard $4-\mathrm{h}{ }^{51} \mathrm{Cr}$ release assay. Yoshizawa and colleagues also reported that tumor draining lymph node cells showed tumor specific therapeutic activity when adoptively transferred after in vitro anti-CD3/IL2 simulation, but failed to display cytotoxic activity in vitro (22). Recently Aruga and colleagues reported that tumor vaccine primed lymph node cells showed potent tumor-specific therapeutic activity in vivo and that the in vitro cytotoxicity could be detected by a long-term cytotoxicity assay (3). Our present findings are consistent with these previous studies. Considering these data, the activated RLN cells might be a little different from the classical cytotoxic $\mathrm{T}$ cells that exert cytotoxic activity in a standard $4-\mathrm{h}{ }^{51} \mathrm{Cr}$ release assay. More precise cell subset analysis may reveal the mechanism of the induction of tumor-specific immunity.

We did not use GM-CSF-virus in this study. However, Dranoff and colleagues have reported that a GM-CSF-gene-transduced tumor had vaccination properties more potent than tumors transduced with genes for other cytokines (IL2, IL4, IL5, IL6, IFN- $\gamma$, TNF- $\alpha$ ) (6). Our previous studies also revealed the therapeutic activity of AIT using GM-CSF-gene-transduced tumor draining lymph nodes $(1,2,13)$. It should be interesting to determine whether IL2 in combination with GM-CSF augments the efficacy of the strategy in an immunocompromised host. Further analysis needs to be pursued.

We thank Dr Chang, Dr Aruga and Dr Arca (University 
of Michigan) for helpful discussions and technical suggestions. We also thank Dr Aoyama and Ms Matsuda (Nippon Medical School) for their assistance.

Received 8 September 1997; and accepted 30 September 1997

\section{REFERENCES}

1. Arca M. J., Krauss J. C., Aruga A., Cameron M. J., Shu S. and Chang A. E. (1996) Therapeutic efficacy of T cells derived form lymph nodes draining a poorly immunogenic tumor transduced to secrete granulocyte-macrophage colony stimulating factor. Cancer Gene Ther. 3, 39-47

2. Arca M. J., Krauss J. C., Strome S. E., Cameron M. J. and Chang A. E. (1996) Diverse manifestation of tumorigenicity and immunogenicity displayed by the poorly immunogenic B16-BL6 melanoma transduced with cytokine genes. Cancer Immunol. Inmunother. 42, 237-245

3. Aruga A., Aruga E., Cameron M. J. and Chang A. E. (1997) Different cytokine profiles released by $\mathrm{CD}^{+}$and $\mathrm{CD}^{+}$tumor-draining lymph node cells involved in mediating tumor regression. J. Leukocyte Biol. 61, 507-516

4. Barth R. J., Bock S. N., Mule J. J. and Rosenberg S. A. (1990) Unique murine tumor-associated antigen identified by tumor infiltrating lymphocytes. $J$. Immunol. 144, 1531-1537

5. Danos O. and Mulligan R. C. (1988) Safe and efficient generation of recombinant retroviruses with amphotropic and ecotropic host ranges. Proc. Natl. Acad. Sci. USA 85, 6460-6464

6. Dranoff G., Jaffee E., Lazenby A., Golumbek P., Levitsky H., Brose K., Jacson V., Hamada H., Pardoll D. and MULLIGAN R. (1993) Vaccination with irradiated tumor cells engineered to secrete murine granulocyte-macrophage colony-stimulating factor stimulates potent, specific, and long-lasting anti-tumor immunity. Proc. Natl. Acad. Sci. USA 90, 3539-3543

7. Fearon E. R., Pardoll D. M., Itaya T., Golumbek P., LeVitsky H. I., Simon J. W., Karasuyama H., Vogelstein B. and Frost P. (1990) Interleukin-2 production by cells bypasses $T$ helper function on the generation of an antitumor response. Cell 60, 397-403

8. Gansbacher B., Zier K., Daniels B., Cronin K., BanNERJI R. and GILBOA E. (1990) Interleukin 2 gene transfer into tumor cells abrogates tumorigenicity and induced protective immunity. J. Exp. Med. 172, 1217-1224

9. Gehan E. (1985) A generalized Wilcoxon test for comparing arbitrary single censored samples. Biometrics 52, 203

10. Golumbek P. T., Lazenby A. J., Levitsky H. I., JafFee L. M., Karasuyama H., Baker $M$. and Pardoll D. M. (1991) Treatment of established renal cancer by tumor cells engineered to secrete interleukin-4. Science 254, 713-716

11. HarT I. J. (1979) The selection and characterization of an invasive variant of the B16 melanoma. Amer. J. Pathol. 97, $587-600$

12. Krauss J. C., Strome S. E., Chang A. E. and Shu S. (1994) Enhancement of immune reactivity in the lymph nodes draining a murine Melanoma engineered to elaborate interleukin-4. J. Immunother: 16, 77-84

13. Kurane S., Arca M. J., Aruga A., Krinock R. A., Krauss J. C. and Chang A. E. (1997) Cytokine as an adjuvant to tumor vaccines: Efficacy of local methods of delivery. Ann. Surg. Oncol. 4, 579-585

14. Marcel T. and Grausz D. (1997) The TMC worldwide gene therapy enrollment report, End 1996. Hum. Gene Ther: 8, 775-800

15. MosmanN T. (1983) Rapid colorimetric assay for cellular growth and survival: application to proliferation and cytotoxicity assay. J. Immunol. Methods 65, 55-63

16. NoRTH R. J., and Dye E. S. (1985) Ly $1^{+} 2^{-}$suppressor T cells down-regulate the generation of $\mathrm{Ly} 1^{-} 2^{+}$effector $\mathrm{T}$ cells during progressive growth of P815 mastocytoma. Immunology 54, 47-56

17. Pellegrini P., Berghella A. M., Beato T. D., Cicia S., Adorno D. and Casciani C. U. (1996) Disregulation in $\mathrm{TH} 1$ and $\mathrm{TH} 2$ subsets of $\mathrm{CD} 4^{+} \mathrm{T}$ cells in peripheral blood of colorectal cancer patients and involvement in cancer establishment and progression. Cancer Immunol. Immunother: 24, 1-8

18. Sambrook J., Fritsch E. F. and Maniatis T. (1989) Molecular Cloning, a Laboratory Manual, 2nd ed. Cold Spring Harbor Laboratory Press, Cold Spring Harbor

19. Strome S. E., Chang A. E., Shu S. and Krauss J. C. (1996) Secretion of both IL-2 and IL-4 by tumor cells results in rejection and immunity. $J$. Immunother with Emphasis on Tumor Immunology 19, 21-32

20. Tepper R. I., Pattengale P. K. and Leder P. (1989) Murine interleukin- 4 displays potent anti-tumor activity in vivo. Cell 57, 503-512

21. WeXLER H. (1966) Accurate identification of experimental pulmonary metastases. J. Natl. Cancer Inst. 36, 641-645

22. Yoshizawa H., Chang A. E. and Shu S. (1991) Specific adoptive immunotherapy mediated by tumor-draining lymph node cells sequentially activated with anti-CD3 and IL-2. $J$. Immunol. 147, 729-737

23. Yoshizawa H., Sakai K., Chang A. E. and Shu S. (1991) Activation by anti-CD3 of tumor-draining lymph node cells for specific adoptive immunotherapy. Cell. Immunol. 134, $473-479$

24. Yu J. S., Burwick J. A., Dranoff G. and Breakefield X. O. (1997) Gene therapy for metastatic brain tumors by vaccination with granulocyte-macrophage colony-stimulating factor-transduced tumor cells. Hum. Gene Ther: 8, 1065-1072 